\title{
A Balaton alatti pannóniai rétegeket mintázó TFM-1/13 kutatófúrás komplex vizsgálatának eredményei
}

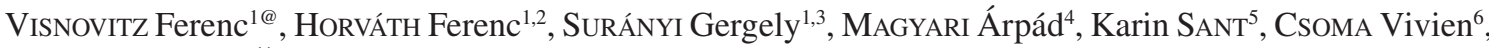 \\ Michal ŠUJAN ${ }^{7}$, Régis Braucher ${ }^{8}$, MAGYAR Imre ${ }^{9}$, SZTANÓ Orsolya ${ }^{10}$, TimÁr Gábor ${ }^{1}$ \\ 'ELTE Geofizikai és Ürtudományi Tanszék, 1117 Budapest, Pázmány Péter sétány 1/C \\ ${ }^{2}$ Geomega Kft., 1095 Budapest, Mester utca 4. \\ ${ }^{3}$ MTA-ELTE Geológiai, Geofizikai és Ưrtudományi Kutatócsoport, 1117 Budapest, Pázmány Péter sétány 1/C \\ ${ }^{4}$ MOL Nyrt., 1117 Budapest, Október huszonharmadika u. 18. \\ ${ }^{5}$ Paleomagnetic Laboratory 'Fort Hoofddijk', Budapestlaan 17, 3584 CD, Utrecht, The Netherlands \\ ${ }^{6}$ ELTE Ốslénytani Tanszék, 1117 Budapest, Pázmány sétány 1/C \\ ${ }^{7}$ Department of Geology and Paleontology, Faculty of Natural Sciences, Comenius University in Bratislava, Slovakia \\ ${ }^{8}$ Aix-Marseille Université, CEREGE, CNRS UM 34, F-13545 Aix-en-Provence, France \\ ${ }^{9}$ MTA-MTM-ELTE Paleontológiai Kutatócsoport, Magyar Természettudományi Múzeum, H-1431 Budapest, POB 137. \\ ${ }^{10}$ ELTE Általános és Alkalmazott Földtani Tanszék, 1117 Budapest, Pázmány sétány 1/C \\ @e-mail: visnovitz.ferenc@gmail.com
}

\section{Results of the TFM-1/13 exploration borehole sampling of Pannonian strata below Lake Balaton}

Abstract

The correlation of high-resolution water seismic profiles measured at Lake Balaton and Pannonian strata in outcrops and boreholes around the lake has been the subject of research for nearly 30 years. The first attempt to find a correlation was presented by SACCHI et al (1998, 1999). They suggested that the silicified carbonate cones (i.e. the "geyserites" mentioned by LócZY 1913) exposed in the Tihany peninsula could be associated with characteristic high-amplitude mounded features identified on seismic profiles.

These mounds are situated at the top of a seismic unconformity, formerly interpreted as a sequence boundary (Pan-2). To test this correlation a drilling was performed in the eastern basin of Lake Balaton in order to collect samples from one of the mounds and the underlying beds. Core samples showed lithological features similar to the Fehérpart section of the Tihany Member - i. e. clays and siltstone - but no silicified carbonates were found. Based on their seismic geometry, this paper interprets the mounds as slumps that formed in the prodelta of progradational delta lobes deposited between 8.4-8.7 Ma in the Lymnocardium decorum biochron. Gamma-intensity and susceptibility measurements combined with observed lithological features and seismic data also revealed the bottom of these slumps. This bottom is characterized by mollusc shell fragments and centimetre-scale, soft-sedimentary deformations.

The drill penetrated the Pan-2 horizon, which turned out to be a sharp boundary between clayey and sandy sediments. Beisotope ages and reverse magnetic polarity of the core suggest that the formation of this horizon occurred during the $\mathrm{C} 4 \mathrm{Ar}$ (9.1-9.8 Ma) chron. Thus it appears to be much older than 7.9 Ma, as was earlier suggested by HoRvátH et al. (2010).

Keywords: lake drilling, Lake Balaton, Pannonian strata, mounded feature, sheet slumping, geyserite cones

Összefoglalás

A Balaton-környéki fúrások, feltárások és a nagyfelbontású vízi szeizmikus szelvények által leképezett üledékek közötti rétegtani korreláció közel 30 éve képezi kutatások tárgyát. A parti és víz alatti rétegsor illesztésére elsőként SACCHI et al. (1998, 1999) adtak korrelációs javaslatot, amely szerint a Tihanyi-félsziget kovás, édesvízi mészkövei (LócZY 1913 gejziritjei) a Balaton alatt is megtalálhatók, és ott mint jellegzetesen nagy amplitúdójú reflexiókkal határolt buckás alakzatok ismerhetők fel. A szeizmikus szelvényeken a buckás alakzatok által kijelölt felszínt egy harmadrendű pannóniai szekvenciahatárként (Pan-2) értelmezték.

A fenti értelmezés ellenőrzésére mederfúrást végeztünk a Balaton keleti medencéjében, és magmintát vettünk a kérdéses rétegtani szintben elhelyezkedő egyik buckából, és néhány méter vastagságban az alatta lévő rétegekből. A fúrás a tihanyi Fehérpart rétegeihez hasonló, agyagos-homokos képződményeket harántolt, vagyis nem támasztja alá SACCHI et al. (1999) felvetését. Az agyagos képződményekből álló buckákat szeizmikus geometriájuk tükrében olyan csuszamlási szerkezetekként értelmezzük, melyek a területet feltöltő progradáló deltalebenyek előterében keletkeztek, mintegy 8,4-8,7 millió éve, a Lymnocardium decorum biokronban. A fúrómagon végzett természetes gamma-intenzitás, mágneses szuszceptibilitás mérések és üledékföldtani vizsgálatok eredményeit a vízi szeizmikus szelvényekkel összevetve sikerült azonosítani a csuszamlásos szerkezetek talpát is. Ez a szeizmikus felület egy molluszkatöredékekkel és centiméteres üledékes deformációkkal jellemezhetô réteg, amelyhez a természetes gamma- és a mágneses szuszceptibilitás szelvényekben is észlelhető változás társul. 
A fúrás harántolta a Pan-2 horizontot is, amely a rétegsorban a mélyebben fekvő homokos és a rátelepülő agyagos képződmények éles határaként jelentkezik. E határ alatti üledékek a Be-izotópos koradatok és reverz mágneses polaritásuk alapján a C4Ar (9,1-9,8 M év) kronban keletkezhettek, tehát úgy túnik sokkal idősebbek, mint a korábban HoRVÁTH et al. (2010) által becsült 7,9 millió év.

Tárgyszavak: mederfúrás, Balaton, pannóniai emelet, buckás alakzat, rétegcsuszamlás, gejziritkúpok

\section{Bevezetés}

A Balaton területén CSERNY \& CORRADA $(1989,1990)$ úttörő méréseit követően 1993 óta folynak nagy- és ultranagy felbontású vízi szeizmikus kutatások, melyek eredményeként mára egy közel $2000 \mathrm{~km}$ összhosszúságú, 2D vonalakból felépülő óriási adatbázis jött létre (TóTH et al. 2010, Balázs et al. 2013, VisNovitZ et al. 2013). A különböző felbontású szeizmikus szelvények segítségével egyedi módon vizsgálhatóak a Balaton medencéjének holocénkéső-pleisztocén üledékei és az alattuk szögdiszkordanciával és jelentős rétegtani hiánnyal települő, kb. 8-10 millió éves, késô-miocén (pannóniai) kőzetek. A szeizmikus adatok a nagy felbontásnak köszönhetôen a térség neotektonikai szerkezeteinek részletes térképezésére is lehetôséget nyújtanak (BADA et al. 2010, VISNOviTZ et al. 2015a).

A Balatont lefedő szeizmikus anyag értelmezésével számos tanulmány foglalkozott (SACCHI et al. 1998, 1999, SZTANó \& Magyar 2007, BADA et al. 2010, HorvátH et al. 2010, NovÁK et al. 2010, ZLINSZKY et al 2010, SZTANó et al. 2013a). Ezek a vizsgálatok a szeizmikus szelvényeken látható geometria (horizontok, vetők) értelmezésére koncentráltak, és eredményeiket a tó közeli fúrások és feltárások rétegsoraival, valamint a tó környékének geomorfológiai és szerkezetföldtani adottságaival vetették össze. A teljes földtani és őskörnyezeti rekonstrukcióhoz, illetve a folyamatok időbeli elhelyezéséhez azonban közvetlen földtani adatokra is szükség van. A Balaton partközeli 0,5-2 km-es sávjában a szeizmikus leképezést a sekély vízmélység és a partok közelében jelentkezô iszapgázok akusztikus árnyékoló hatása (VISNOvitz et al. 2015b) megakadályozza, emiatt a parti fúrások és feltárások szeizmikus szelvényekkel való korrelációja egyelóre nem elég pontos.

A tó területén a negyedidőszaki üledékek jellemzéséhez értékes földtani információt szolgáltatnak a MÁFI 198090-es években mélyített sekély fúrásai, az ún. „Tó-fúrások” (CSERNY 2002). Ezek azonban legfeljebb néhány méter vastagságban harántolták a kvarter alatti pannóniai képződményeket, így azokról igen kevés ismeretet nyújtanak. A felhozott pannóniai mintákon kormeghatározás nem történt, a rövid magszakasz miatt a fúrómagok korrelációja a parti szelvényekkel fel sem merült. A fentiek tükrében a szeizmikus szelvényeken látható pannóniai rétegsor időbeli elhelyezéséhez, ciklicitásának és üledékképződési folyamatainak megértéséhez a Balaton alatti pannóniai üledékek célzott mintázása volt szükséges.

A vízi szeizmikus szelvényeken azonosítható pannóniai horizontok időbeli elhelyezése jelenleg egy szeizmikus horizont és egy, a Tihanyi-félszigeten megfigyelhetô, feltételezhetôen eróziós felület korrelációján alapul. Ez a felület a pannóniai sziliciklasztos üledékek (Tihanyi Tagozat), és az azokra közvetlenül települő vulkanit és/vagy édesvízi mészkőkúpok (,gejzírit”, Lóczy 1913) között húzódik (SACCHI et al. 1999). SACCHI et al. (1999) majd később HoRvÁTH et al. (2010) geometriai megfontolások alapján ezt a harmadrendû szekvenciahatárként értelmezett felületet (Pan-2) a szeizmikus szelvényeken is felismerni vélték, és korát 8,7 millió évesnek (SACCHI et al. 1998), majd később a rátelepülő vulkáni képződmények nagy pontossággal ismert radiometrikus korával (7,96 $\pm 0,3 \mathrm{M}$ év, WIJBRANS et al. 2007) azonosnak gondolták (HoRvÁTH et al. 2010).

Az 1993-as nagyfelbontású szelvényeken a Pan-2 horizont helyét egy adott rétegtani szintben sorakozó, általában nagy pozitív amplitúdójú reflexiókkal jelentkezô buckás alakzatok alatt, egy reflexióelvégzôdések mentén kirajzolódó felületen jelölték ki. A buckás alakzatokat a Tihanyifélsziget analógiájára mint kovás, édesvízimészkő-kúpok (,gejzírit”) értelmezték, és a szárazulati kitettség, így a szekvenciahatár egyértelmú bizonyítékának tartották.

A buckás alakzatokat a 2005-ös többcsatornás és a későbbi, nagyobb felbontású egycsatornás szelvények is leképezték a Balaton keleti medencéjében (1. ábra). Ez lehetôvé tette a kapcsolódó rétegtani szint és a buckák elterjedésének térképezését (1. ábra, e). A szeizmikus horizontok korrelációja alapján a kérdéses nagy amplitúdójú objektumokat sikerült az ultranagy felbontású szelvényeken is azonosítani (1. ábra, $c, d$ ), és ezáltal olyan célterületet kitúzni, ahol az „édesvízi mészkô" kúpokon alapuló rétegtani hipotézis sekély (<50 m) fúrással ellenôrizhető (VISNOvitz et al. 2014). Az ultranagy felbontású szeizmikus szelvények feltárták a buckás alakzatok belsô struktúráját is (1. ábra, $c, d)$, emellett rámutattak, hogy a kérdéses alakzatok nem mindenhol települnek közvetlenül a Pan-2 felszínen, hanem többnyire valamivel felette, de még ugyanabban a szeizmikus rétegtani egységben helyezkednek el. Mivel a buckák belső szerkezete jól magyarázható volt egy héjasan felépülő „édesvízimészkő-forráskúp" modellel, a korreláció megerősítése érdekében a buckákat felépítő anyag fúrással történő mintázása mellett döntöttünk. A fúrást (TFM-1/13) egy elôzetes szeizmikus felmérést követôen 2013 októberében valósítottunk meg.

Jelen tanulmány célja a tó alatti buckák egyikét harántoló sekélyfúrás (TFM-1/13) rétegsorának bemutatása, valamint a fúrómagokon végzett geofizikai (természetes gamma-intenzitás, mágneses szuszceptibilitás), mágnesrétegtani és Be-izotópos vizsgálatok eredményeinek ismertetése. Az új eredmények fényében kísérletet teszünk a buckás alakzatok eredetének magyarázatára és a képződmények korának meghatározására. A fúrásban található rétegsort és a koradatokat összehasonlítjuk a Pan-2 felszín mentén mutatkozó jellegzetességekkel is, és vizsgáljuk az ezen felszín segítségével végzett rétegtani korreláció helytállóságát. 

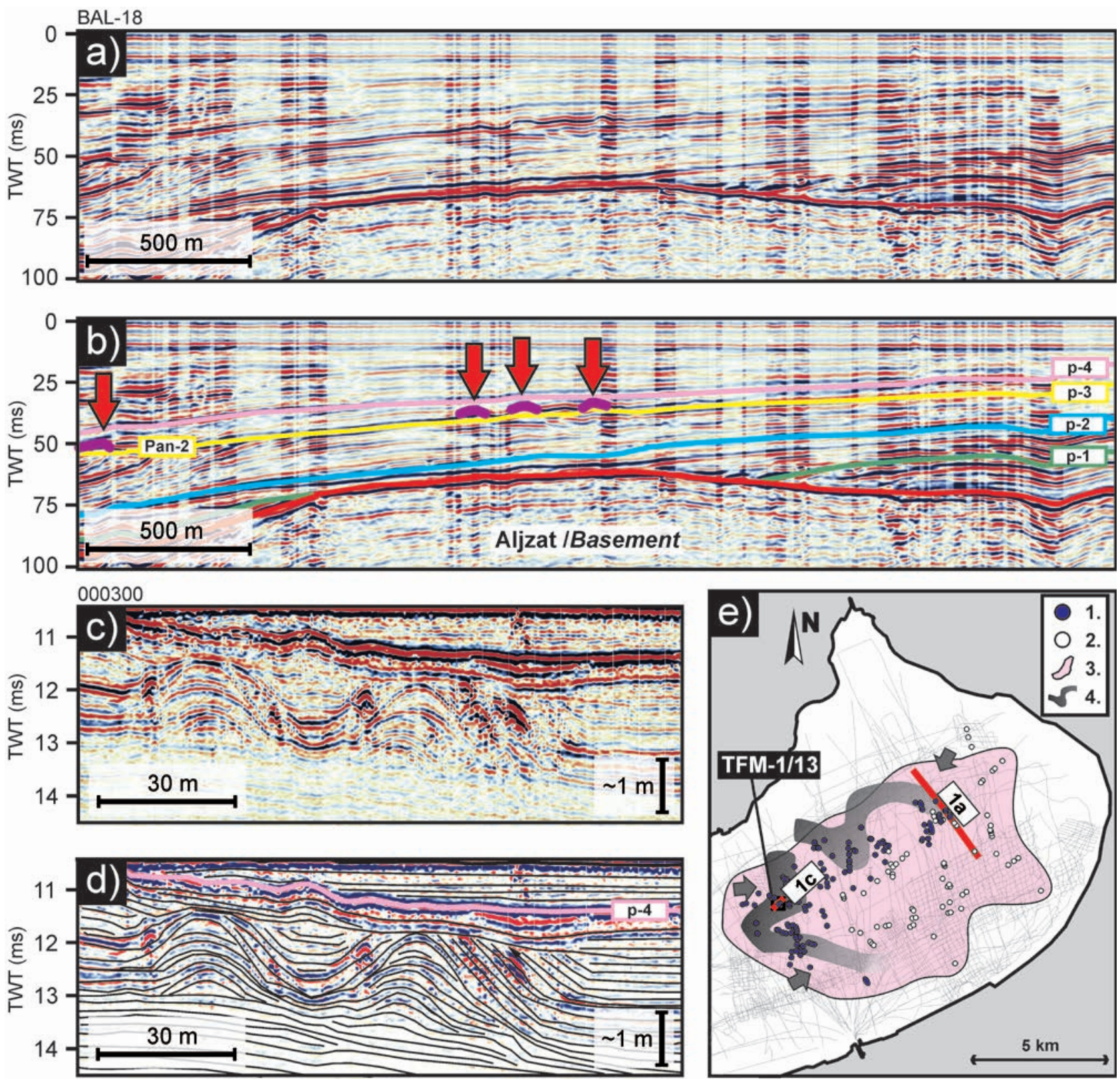

1. ábra. A Balaton alatti buckás alakzatok szeizmikus képe és elterjedése a Balaton keleti medencéjében (VISNOviTZ et al. 2014). a)-b) Buckák a Pan-2 szeizmikus horizont felett egy nagyfelbontású, többcsatornás szeizmikus szelvényen, c)-d) A buckák ultranagy felbontású szeizmikus képe és belsỏ szerkezetének vonalas értelmezése, e) A buckás alakzatok előfordulása a vízi szeizmikus adatok alapján. 1 -bucka ultranagy felbontású szelvényen, 2-bucka nagyfelbontású szelvényen, 3 - a buckák előfordulási területe, 4 - a deltalejtő szeizmikus szelvények alapján feltételezhetỏ lefutása a buckák keletkezése idején. p-1 - p-4: deltaciklus-határok a pannóniai üledékekben

Figure 1. Mounded features and their distribution in the eastern sub-basin of Lake Balaton (VISNOVITZ et al. 2014). a)-b) Mounds above Pan-2 horizon on a high-resolution multichannel seismic profile. c)-d) Mounds in ultra-high resolution seismic profile and the interpretation of their inner structure. e) Occurrence of mounded features based on seismic surveys. 1 - mound on ultra-high resolution profiles, 2-mound on high-resolution profiles, 3-area of mound occurrences, 4-supposed position of delta front in the time of mound formation based on seismic profiles. p-1 - p-4: boundaries of consecutive deltaic cycles in Pannonian strata

\section{A mederfúrás kitúzése és az alkalmazott fúrási technológia}

A buckás alakzatokat mintázó fúrás kitúzését sưrú hálózatban elvégzett, ultranagy felbontású szeizmikus szelvényezés elózte meg. A szelvényhálót egy olyan célterületen vettük fel, amelyen a korábbi mérések alapján a buckákat sekély mélységben és jó minőségben sikerült leképezni. A mérés Alsóörs előtt, az északi parttól mintegy 3,5 km-rel D-i irányban, egy kb. 400×400 méteres területen, 40×40 méteres rácshálóban történt. Az új „,kvázi 3D” szeizmikus blokkban térképeztük a buckás alakzatok talpát és felső burkoló görbéjét, majd képeztük a kettő közötti rétegtani egység vastagságát (2. ábra). A vastagság térképen 1-2 méter vastag, 1500-4000 m² területú, ÉNy-DK irányban kissé megnyúlt, ovális objektumok rajzolódtak ki. A fúrás helyét a térképezett terület déli részén található, nagyjából $2500 \mathrm{~m}^{2}$ területú, legmagasabb buckára túztük ki, két szeizmikus 


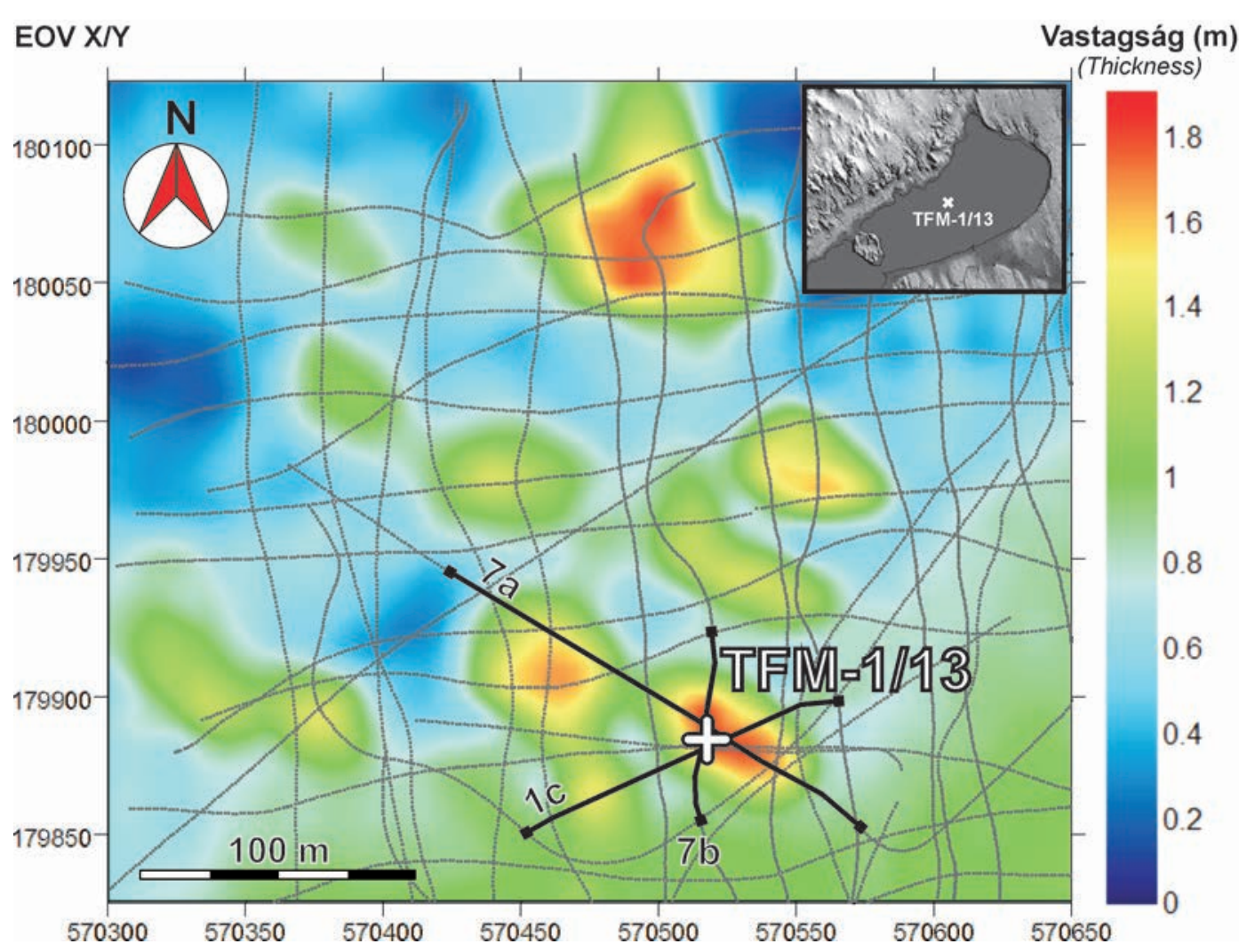

2. ábra. A buckák elterjedése és vastagsága a vizsgálati területen a 2013-as ultranagy felbontású szeizmikus szelvényháló alapján Figure 2. The shape and thickness of the mounds at the study area based on ultra-high resolution seismic survey of 2013

szelvény metszésvonalában. A fúrás EOV koordinátái $\mathrm{X}=570516,9 ; \mathrm{Y}=179890,6$ voltak.

A fúrást 2013. október 14-15-én, DGPS segítségével pozicionált és jól lehorgonyzott uszályról végeztük el a Geovil Kft. és az Óriás Line Kft. közremúködésével. A fúrás M.I.9 típusú fúrógéppel történt, a magmintát Geobor-S típusú mintavevő fej segítségével, zárt PVC csövekbe emeltük ki. A fúrás 0 métere a Balaton aktuális vízszintjében (104,28 mBf) lett meghatározva, talpmélysége 19,5 méter volt. A kb. 4,4 m víz alatt a mintavételhez szükséges fenékzárásig 4,6 m üledéket fúrt át a fúró. A pannóniai rétegsorból, 9,00 és 19,5 méter között 1,5 méteres szakaszokban (M1-M7), összesen 6,64 méter magot nyertünk (63\%-os magkihozatal). A fúrást az időközben megváltozott időjárási viszonyok és a magcső megszorulása miatt tovább mélyíteni nem lehetett.

\section{A TFM-1/13 fúrás rétegsora}

A fúrás sötétszürke, finomhomokos, aleuritos, helyenként szénült növényi maradványokat, illetve molluszkahéjakat és azok törmelékét tartalmazó agyagot, aleurolitot és szerkezetmentes, illetve párhuzamos-lemezes vagy keresztlemezes finom-aprószemcsés homokot harántolt (3-4. áb$r a$ ). A rétegsorban négy nagyobb kifejlődés volt elkülöníthető:
I. 9,00-12,35(?) m: Sötétszürke, molluszkahéjakat és azok törmelékét tartalmazó, szerkezetmentes agyag (3. áb$r a, a)$, mely szürke-sötétszürke aleuritos agyagra települ (3. $a ́ b r a, b$ ). Talpa éles, egyenetlen felület, melynek mélysége a maghiány miatt nem volt pontosan megadható. A kifejlődés talpa valahol 12,35 m és 13,48 m között húzódik (3. ábra, c). Néhány nap száradás után az agyag és az aleuritos agyag határán cm-es nagyságú, lángalakú, üledékes deformációs szerkezetek körvonalai rajzolódtak ki.

Az egységben jól kivehetô molluszkahéjas szintek 9,20 mnél, 9,55-9,83 m és 10,28-10,32 m között, valamint 10,90 m-nél azonosíthatók. Az ôslénytani vizsgálatokhoz mintát a 9,50-9,75 m között található szintből vettünk, ahol a milliméter méretûre darált héjtöredékek mellett, cm nagy, ép, de rossz megtartású teknôk is előfordultak (3.ábra, d). 10,94 mnél a mag külsố részén 1-1,5 cm átmérôjû, sötétszürke, aprószemcsés homokkőkavicsok voltak, melyek a mag palástjára feltehetőleg csak technológiai okokból kerültek. A rétegtani szintet az M1 (9,0-10,5 m; magkihozatal: 1,5 m), M2 (10,50-12,00 m; magkihozatal 1,5 m), és az M3 (12,0013,50 m; magkihozatal: 0,37 m - 3 db, egyenként 7, 14 és $15 \mathrm{~cm}$-es szakaszban) fúrómagok mintázták (3. ábra, e).

II. 12,35(?)-16,50 m: Gyengén-közepesen osztályozott, sárgásbarna (M3 mag alján), majd szürke, csillámos, agyagos-aleuritos, finom-aprószemcsés homok, amely helyenként szénült növényi maradványokat, valamint 13,50-15,00 m között cm nagyságrendú üledékes deformációkat tartalmaz. 


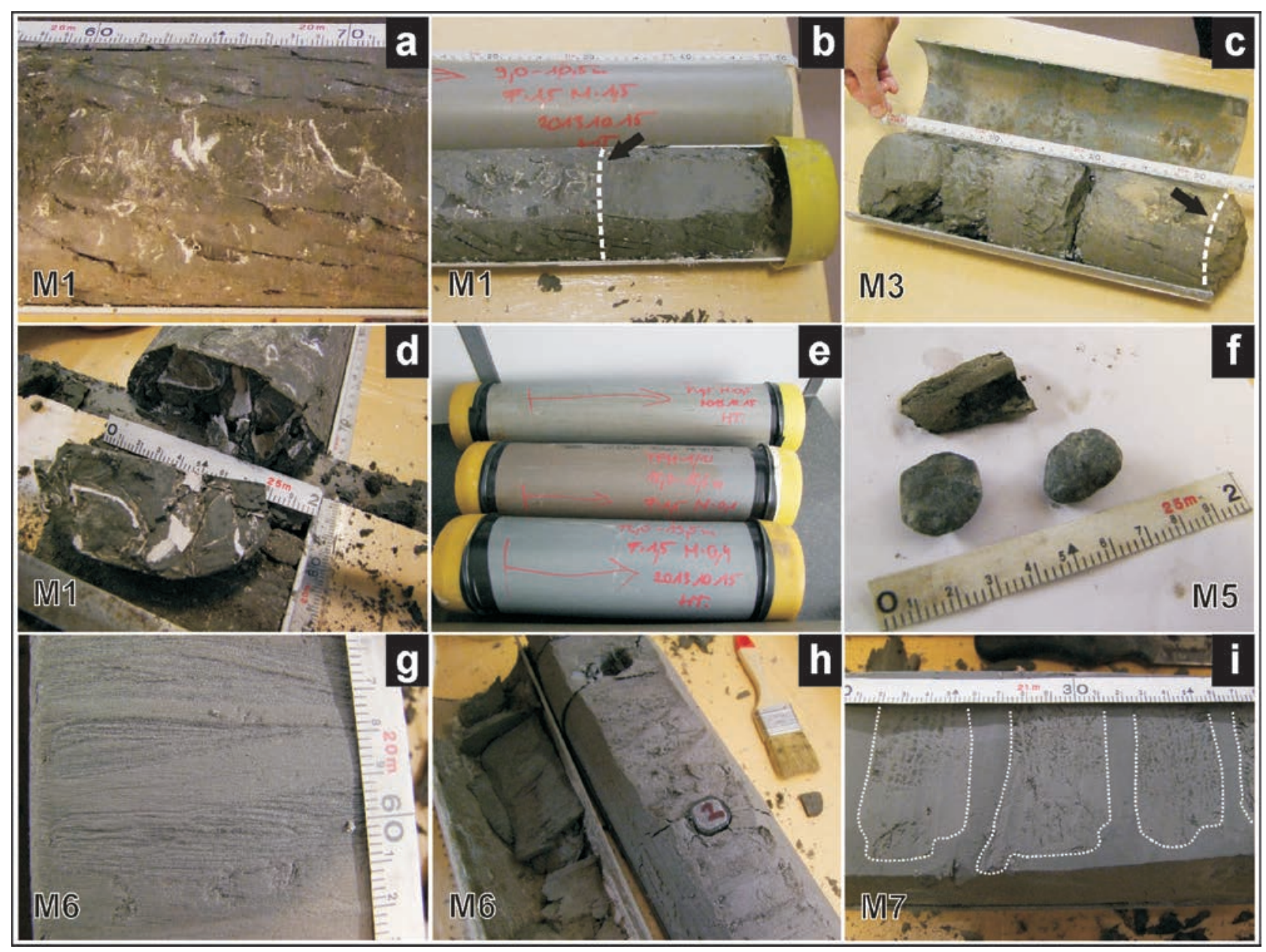

3. ábra. A TFM-1/13 mederfúrás fúrómagjának különböző szakaszai. a) Szürke, héjtöredékekben gazdag, szerkezetmentes agyag az M1 mag felső részéből. b) A szürke, héjtöredékekben gazdag, szerkezetmentes agyag és a sötétszürke aleuritos agyag határa az M1 mag alsó szakaszában. c) Az M3 mag - a fehér szaggatott vonal az aleuritos agyag és az alatta települő sárgásbarna finomszemcsés homok határát jelzi. d) Az őslénytani vizsgálatok mintavételi helye (M1 mag, 9,50-9,75 m). e) Magok zárt PVC csövekben. f) Kavics az M5 magszakaszból. g) Keresztlemezes finom-aprószemcsés homok az M6 magban. h) Mintavétel magnetosztratigráfiához az M6 magból. i) Lencsés-hurkás agyagbenyomulások az M7 magban

Figure 3. Core segments of TFM-1/13 borehole a) Grey, unstratified clay with mollusc shell fragments in M1 core. b) Boundary of the grey unstratified clay and dark grey silty clay in the bottom of M1 core. c) M3 core - white dashed line indicate the boundary of silty clay and brownish fine-grained sand. d) Sampling place for biostratigraphy (M1 core, 9.50-9.75 m). e) Cores in PVC tubes. f) Gravels from the M5 core. g) Cross-laminated fine to very fine grained sand in M6 core.h) Sampling for magnetostratigraphy in M6 core. i) Clay imbedding/lenses in $M 7$ core

Utóbbi deformációk 0,5-3 cm vastag, megnyúlt, deformált agyaglencsék betelepüléséhez kötődnek, melyek mélyebbről vett fúrómagok bélyegei alapján vélhetően a fúrási technológia eredményei. A rétegtani szintből a magkihozatal nagyon alacsony volt. A mintákat az M3 mag alsó kb. 1 cm-e, valamint az M4 (13,50-15,00 m, magkihozatal 0,50 m-3 db, egyenként 27, 18 és $5 \mathrm{~cm}$ szakasz) és M5 (15,00-16,50 m, - 2 db, egyenként 5-5 cm-es szakasz) magok tartalmazzák. Az M5 magszakaszban $3 \mathrm{db}$ aprószemcsés, csillámos homokkőkavicsot találtunk (3. ábra, f). A kavicsok anyaga, kerekítettsége és felületük mállottsága alapján feltételezhető, hogy azok a pannóniai rétegsort elnyesô eróziós felszínnél található kavicsos rétegból (CSERNY 2002, MÁRTON et al. 2007), a fúrás során kerülhettek a magcsô aljára.

III. 16,50-18,87 m: Szürke-világosszürke, párhuzamos-lemezes, illetve keresztlemezes, csillámos, aleuritos, közepesen osztályozott, finom-, aprószemcsés homok (3. ábra, g), helyenként aleurolit-, illetve agyagbetelepülésekkel, melyek közül utóbbi főleg a fúrás talpán volt jellemző. A kifejlődés anyagát az M6 (16,50-18,00 m, magkihozatal 1,15 m) és az M7 (18,00-19,50 m, magkihozatal $1,5 \mathrm{~m})$ magszakaszok tartalmazzák, melyekből magnetosztratigráfiai vizsgálatokhoz mintavétel történt (3. ábra, h). Az M6 mag talpának és az M7 mag tetejének azonos bélyegei miatt feltehetőleg a két alsó mag egymás közvetlen folytatása. A rétegeket az M7 magnál a magcsô mentén több cm-es, de változó vastagságú, hullámzó falú, szürke-sötétszürke agyagpalást vette körbe, amely 5-15 cm-es közönként összeér, 2-5 cm vastag, látszólagos, hurkás illetve lencseszerú betelepülésekhez hasonlítva (3. ábra, i). Feltehetôen a fúrás során a mag alsó szakaszán található szerkezetmentes agyag folyósodhatott, és a magcső fala benyomult a homokba. Utóbbit a fúrást megnehezítő hullámzás is segíthette. 
IV. 18,87-19,50 m: Sötétszürke, helyenként centiméter vastag, agyagos-aleurolitos, rétegzetlen agyag, mely az M7 mag alsó 63 cm-ében van jelen.

\section{A fúrómagon végzett vizsgálatok fontosabb eredményei}

Mágneses szuszceptibilitás, természetes gamma-intenzitás

\section{Ösmaradványok, biosztratigráfia}

Az ősmaradványok meghatározására a fúrómag 9,509,75 m közötti szakaszából vettünk mintát, onnan, ahol az alapvetően mm-es nagyságú héjtöredékek között helyenként nagyobb méretú kagylóhéjak is előfordultak. A maradványok rossz megtartása miatt a puhatestúek pontos meghatározása többnyire nem volt lehetséges. A mintázott szakaszban található héjak nagy része a Congeria balatonica
A két felső, teljes magszakaszban Bartington MS2 típusú, a mágneses szuszceptibilitást mérô szondával 5 cm-enként megmértuik az agyag szuszceptibilitását $(\kappa)$, illetve Canberra HPGe félvezetô detektoros gamma-spektrométerrel (hatásfoka 14\%, felbontása 1,8 keV 1332 keV) 10 cm-enként meghatároztuk a természetes gamma-intenzitás (TG) értékét. A gamma-mérések átlagosan 1-1,5 óráig zajlottak, és nagyjából 10\%-os bizonytalanság mellett adják vissza a magon mérhető intenzitást. A mérések eredményeit a 4. ábra mutatja.

A legfelső 1,5 méteres magszakaszban a mágneses szuszceptibilitás értékekben a mélységgel egy csökkenô tendencia figyelhető meg, míg a második mag esetében a szuszceptibilitás stabilan alacsonyabb értéket mutat. A második magra jellemző alacsony értéket az elsố mag (M1) alján, 10,3 méterben veszi fel a görbe.

A gammaintenzitás-mérések alapján a két felső magban (M1, M2) a szuszceptibilitás eredményekhez hasonlóan két szakasz különíthető el. Az M2 mag alján a gamma intenzitás még relatíve nagy, majd a mag teteje felé haladva értéke fokozatosan csökken. Az M1 mag talpán az intenzitás érték még alacsony, de kb. 10,3 méternél egy határozott növekedés figyelhetô meg. E felett az M2 magra jellemző csökkenő tendencia ismétlődik. A mágneses szuszceptibilitás és gammaintenzitás görbékkel kimutatott két szakasz a kőzetminőség finom változásában is észlelhető volt.

A felső csökkenő szuszceptibilitást és emelkedő gamma értékeket mutató szakasz alapvetően szürke, szerkezetmentes agyagból, míg az alsó stabil szuszceptibilitású és ismételten emelkedő gamma sugárzást mutató szakasz pedig sötétszürke aleuritos agyagból áll.

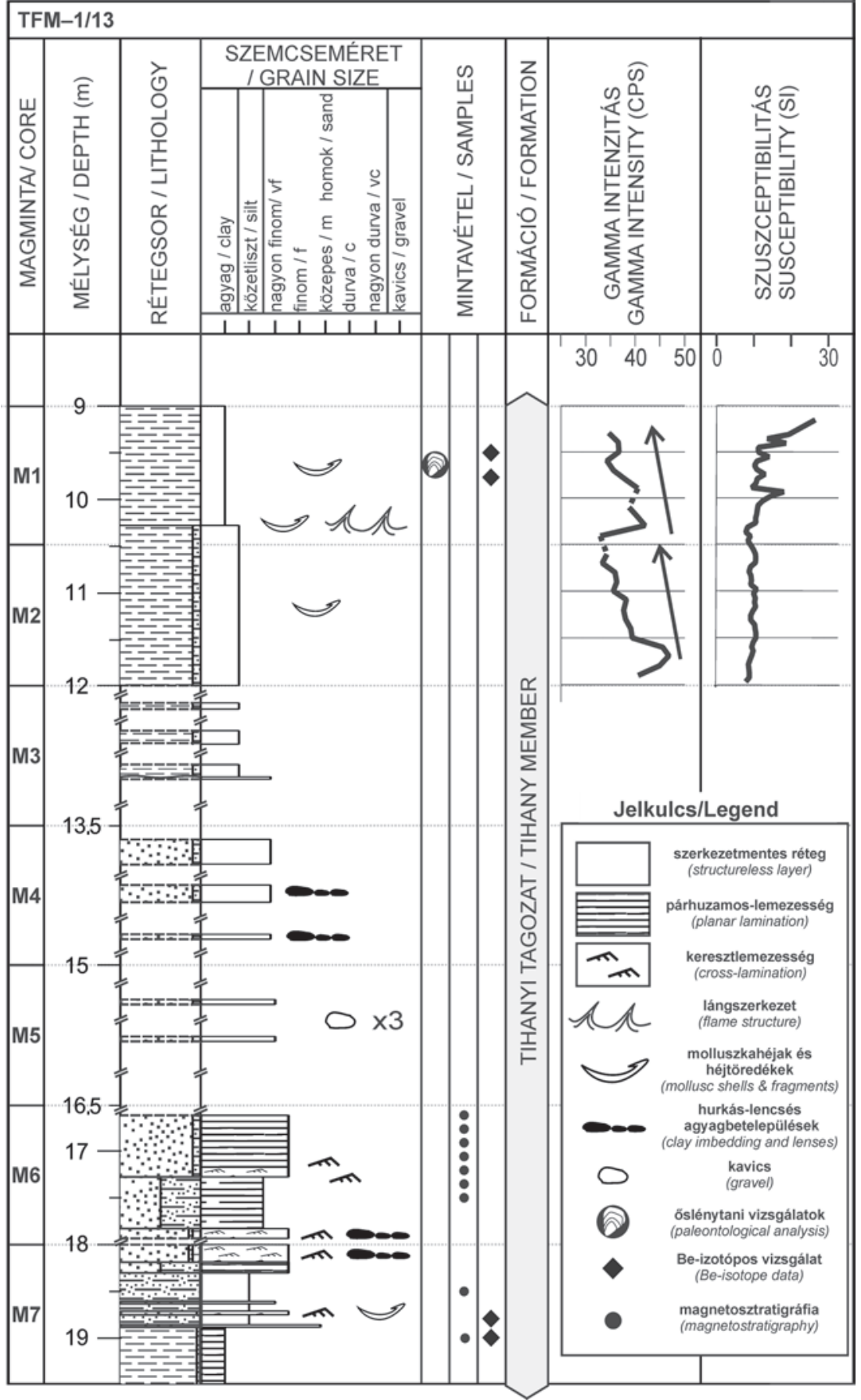

4. ábra. A TFM-1/13 mederfúrás rétegsora a Be-izotópos és magnetosztratigráfiai mintavételi helyek feltüntetésével

Figure 4. Lithological column of TFM-1/13 with the indication of sample locations for Be-isotopic and magnetostratigraphic measurements 
PARTSCH fajt képviselte, de ezek mellett előfordult egy-két csiga (Theodoxus cf. turbinatus (FuCHs), Gastropoda sp.) és más kagyló (Dreissena sp., Lymnocardium decorum [FuCHS]) is. Ezek a fajok előfordulnak a Tihany, fehérparti rétegekben is, és biosztratigráfiai szempontból is ugyanoda, a Lymnocardium decorum zónába tartoznak. A zóna felső korhatárát éppen a tihanyi vulkanitok segítségével 8 millió évesnek (SzTANó et al. 2013a), alsó határát áttételes korrelációk alapján 8,7 millió évesnek becsüljük.

A mikropaleontológiai vizsgálat során a sötétszürke, molluszkahéjakban gazdag agyagból kis diverzitású, de nagy egyedszámú kagylósrák fauna példányai kerültek elő. A teknők jó megtartásúak, főként kettős teknők. Egyes teknők feketék, piritesedtek. Ez valószínúleg az üledékképződés során kialakult reduktív viszonyokra utal. A mintában az ostracodákon kívül halcsigolya, ragadozó halfog, otolith és csiga embrió is előfordult. Az otolithot a sügéralakúak (Perciformes) közé tartozó Morone genusba lehetett besorolni (BosNAKOFF 2013). A kagylósrák együttesben összesen nyolc taxont sikerült elkülöníteni: $C y p$ rideis seminulum (REUSS), Hemicytheria sp., Xestoleberis sp., Candona (Caspiolla) sp., Candona (Caspiocypris) sp., Candona (Sinegubiella) sp., Amplocypris abscissa (REuss). A faunában nagy egyedszámmal megjelenő Cyprideis seminulum a KollmanN (1960) által a Bécsimedencében felállított zonáció alapján a pannóniai emeleten belül a G-zónát jelöli ki. A csak eurihalin alakokból álló együttes jól szellőzött, gyengén mozgatott, limnobrakk környezetre utal. A mintában a Cyprideis seminulum példányai dominálnak, ami pangóvízi környezetet vagy annak közelségét jelzi. Jelentős mennyiségben megjelennek a Hemicytheria genus képviselői is, az Amplocypris abscissa és a Candona-félék mellett, melyek mio-mezohalin (5-9\%o közötti) sekély szublitorális (10-15 m mély) környezetre utalnak (SzUROMI-KoRECZ 1989, Rundić et al. 2011).

\section{Magnetosztratigráfia}

A fúrás 16,50-19,50 m közötti szakaszából magnetosztratigráfiai vizsgálatokhoz vettünk mintákat. A fúrómag felületének megtisztítása után múanyag mintavevő kupakokkal 9 db mintát vettünk a mag tengelyére merólegesen, megjelölve a felfelé mutató irányt. 16,50-18,00 m között 7 db mintát vettünk, 15 cm-es mintavételi közzel, míg 18,0019,50 m között 2 db mintát: 18,50 m-nél és 19,00 méternél (4. ábra). A lemágnesezés és az inklináció meghatározása DANKERS \& ZIJDERVELD (1981) alapján, egy automatizált, váltóterû magnetométerrel (2G Enterprises, DC Squid típusú), 2-20 mT lépésközökkel, 100 mT maximális értékig történt. Termikus lemágnesezésre a mintatartók anyaga miatt nem volt lehetőség. A mérések során 7 minta mutatott szignifikáns remanens mágnesezettséget, közülük három a 20-100 mT (trenderôsség: ,jó”, lásd 5. ábra, a), míg négy a 15-45 mT tartományban (trenderôsség: „,közepes”, lásd 5. $a ́ b r a, b)$ volt stabil. Két minta nem mutatott értékelhető eredményt (trenderôsség: ,gyenge”, lásd 5. ábra, c). A mágneses vizsgálatok eredményeit az I. táblázat foglalja össze. A mérések alapján a mintázott rétegsor 16,50-19,50 m közötti szakaszát reverz mágneses polaritás jellemezi.

\section{Be-izotópos kormeghatározás}

A fúrás által harántolt üledékek korát Be-izotópos módszerrel (cf. BouRLÈs et al. 1989, LEBATARD et al. 2010) határoztuk meg. A Középső-Paratethys késő-miocén sziliciklasztos üledékeinek numerikus kormeghatározása tekintetében ez a módszer egyelőre még kísérleti és kalibrálási

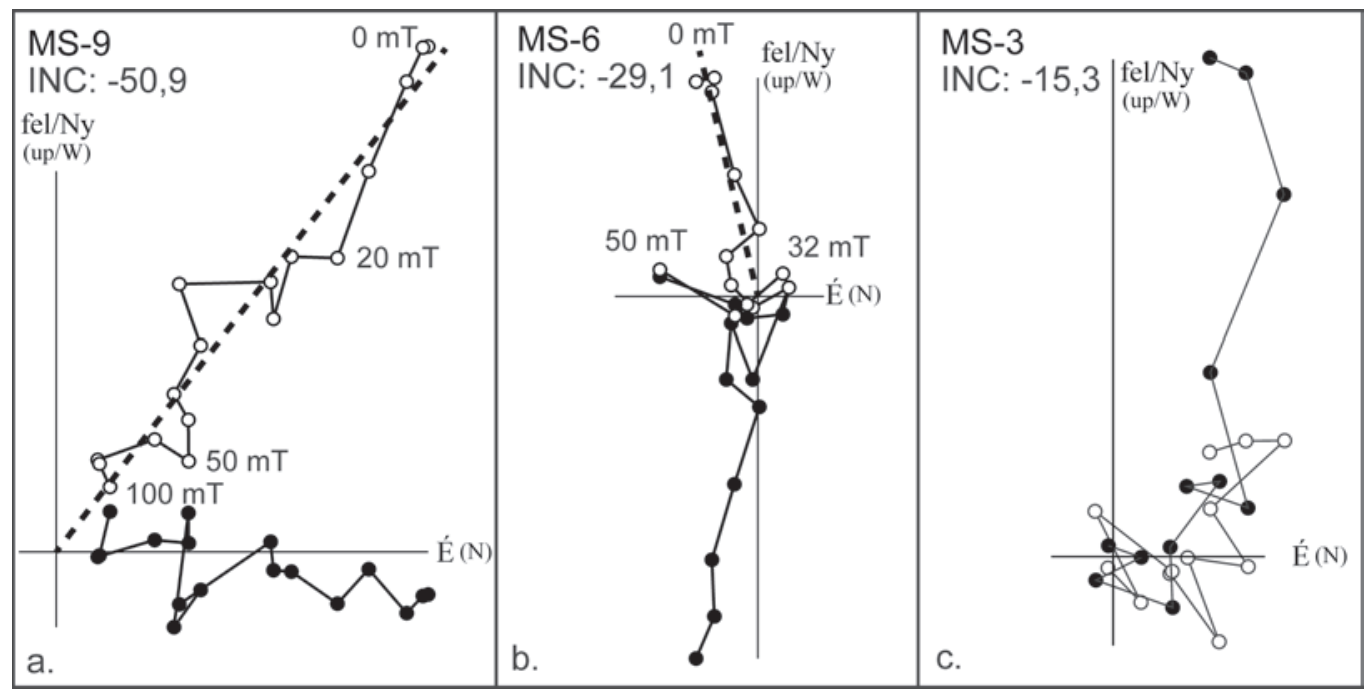

5. ábra. Az MS-9, MS-6 és MS-3 minták lemágnesezéséből származó Zijderveld diagramok (ZIJDERVELD 1967). A szaggatott trendvonal által meghatározott átlagos inklináció értékek (INC) (KIRSCHVINK 1980) a bal felsỏ sarokban vannak feltüntetve. A fehér (fekete) körök a meghatározott inklináció (deklináció) értékeket mutatják a lemágnesezés egyes lépései után. a) MS-9 minta, trenderősség: ,jó”, b) MS-6 minta, trenderősség: „közepes”, c) MS-3 minta, trenderősség: „gyenge”

Figure 5. Zijderveld projections (ZIJDERVELD 1967) of samples MS-9, MS-6 and MS-3. Mean inclination values (INC) of plotted dashed line (KIRSCHVINK 1980) shown in upper left corner; open (closed) circles denote inclination (declination) steps a) MS-9 sample, quality of trend: "good", b) MS-6 sample, quality of trend: "medium", c) MS-3 sample, quality of trend: "weak" 
I. táblázat. A fúrómagból vett minták mágnesrétegtani jellemzése

Table I. Magnetostratigraphic characteristics of the core samples

\begin{tabular}{|c|c|c|c|c|c|}
\hline $\begin{array}{l}\text { Mintaszám (mélység) } \\
\text { Sample (depth) }\end{array}$ & $\begin{array}{c}\text { Stabil tartomány } \\
\text { Stable range } \\
(m T)\end{array}$ & $\begin{array}{l}\text { Trenderössége } \\
\text { Quality of trend }\end{array}$ & $\begin{array}{l}\text { Inklináció } \\
\text { Inclination } \\
\left({ }^{\circ} \mathrm{C}\right)\end{array}$ & $\begin{array}{c}\text { Átlagos intenzitás } \\
\text { Mean intensity } \\
(\mu \mathrm{A} / \mathrm{m})\end{array}$ & $\begin{array}{l}\text { Mágneses polaritás } \\
\text { Inclination polarity }\end{array}$ \\
\hline MS-1. (16,60 m) & $20-32$ & közepes (medium) & $-18,3$ & 190 & Reverz (Reverse) \\
\hline MS-2. $(16,75 \mathrm{~m})$ & $15-32$ & közepes (medium) & $-22,5$ & 85 & Reverz (Reverse) \\
\hline MS-3. $(16,90 \mathrm{~m})$ & $15-30$ & gyenge (weak) & $-15,3$ & 169 & $?$ \\
\hline MS-4. $(17,05 \mathrm{~m})$ & $15-45$ & közepes (medium) & $-39,3$ & 171 & Reverz (Reverse) \\
\hline MS-5. $(17,20 \mathrm{~m})$ & $20-50$ & jó $($ good $)$ & $-35,0$ & 266 & Reverz (Reverse) \\
\hline MS-6. $(17,35 \mathrm{~m})$ & $15-30$ & közepes (medium) & $-29,1$ & 218 & Reverz (Reverse) \\
\hline MS-7. $(17,50 \mathrm{~m})$ & $15-45$ & gyenge (weak) & 41,9 & 87 & $?$ \\
\hline MS-8. $(18,50 \mathrm{~m})$ & $25-70$ & jó $($ good $)$ & $-37,9$ & 154 & Reverz (Reverse) \\
\hline MS-9. $(19,00 \mathrm{~m})$ & $20-100$ & jó $(\operatorname{good})$ & $-50,9$ & 391 & Reverz (Reverse) \\
\hline
\end{tabular}

stádiumban van, de a Kisalföldön végzett mérések alapján a hazai pannóniai üledékek kormeghatározására is várhatóan használható (ŠUuAN et al. 2015, 2016). Be-izotópos kormeghatározásra tesztjelleggel összesen 4 mintát vettünk. Kettôt a fúrómag felsố részéből (M1), kettốt pedig a legalsó 1,5 méteres szakaszból (M7) (4. ábra). Ezek a minták a balatoni szeizmikus adatok értelmezése alapján két különböző deltaciklushoz tartoznak (VISNOVITZ 2015), melyek között egy ciklushatár (p-3, 1. ábra) azonosítható. Utóbbi p-3 horizont azonos a SACCHI et al. (1999) és HoRvÁTH et al. (2010) által értelmezett Pan-2 felülettel, melynek korát a mérésekkel idôhatárok közé kívántuk szorítani. A minták korát a francia ASTER AMS laboratóriumában, megfelelő minta-elókészítés után nemzetközi standardokkal kalibrálva határoztuk meg (ŠUJAN et al. 2016). A kapott berillium korokat és azok hibáját a II. táblázat tartalmazza.

II. táblázat. A fúrómagból vett minták berillium kora

Table II. Be ages of some core samples

\begin{tabular}{|c|c|c|c|}
\hline $\begin{array}{c}\text { Minta } \\
\text { Sample }\end{array}$ & $\begin{array}{c}\text { Fúrásbeli mélység (m) } \\
\text { Measured depth }\end{array}$ & $\begin{array}{c}\text { Berillium kor } \\
\text { Berillium age (Ma) }\end{array}$ & $\begin{array}{c}\text { Bizonytalanság } \\
\text { Uncertainity (My) }\end{array}$ \\
\hline 1. & 9,52 & 8,65 & $\pm 0,42$ \\
\hline 2. & 9,75 & 8,84 & $\pm 0,4$ \\
\hline 3. & 18,8 & 9,65 & $\pm 0,43$ \\
\hline 4. & 19 & 9,36 & $\pm 0,4$ \\
\hline
\end{tabular}

A II. táblázatban feltüntetett értékek relatíve nagy hibákkal terheltek, ennek ellenére az általuk megadott időtartomány viszonylag jól definiálható, kb. 8,6-9,6 M év. Mivel a fúrás által harántolt deltaciklusokon belül nem várunk nagy időeltéréseket, ezért a fúrás felső-, és alsó részéből származó mintapárokat célszerú együttesen értelmezni.

A mintapárokból átlagokat képezve a felsố ciklus

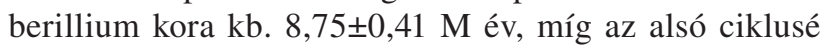
9,52 $\pm 0,41$ M év. Korábbi munkák a balatoni pannóniai üledékek, így a Tihanyi Tagozat korát a területen 8,0 és 8,7 millió évesre teszik (Csillag et al. 2010, MagYar et al. 2013, SzTANó et al. 2013a). Az M7 magra vonatkozó korok ennél lényegesen idősebbnek mutatkoztak, tehát nem illeszkednek a jelenlegi modellbe. Az M1 magból származó koradatok hibahatáron belül illeszthetốk a fenti időszakba.

\section{A buckás alakzatok eredete}

A fúrás rétegsorát, a szuszceptibilitás és a természetes gamma-intenzitás mérések, a bio-, magnetosztratigráfia és a geokronológia eredményeit összevetettük az ultranagy felbontású szeizmikus szelvényeken látható rétegtani képpel (4. és 6. ábra). A fúrási rétegsort a tófenék szintjéhez illesztettük. Megfelelő idő-mélység összefüggés hiányában az iszap esetében, a korábbi tavi fúrások és szeizmikus szelvények illesztéséból meghatározott $1600 \mathrm{~m} / \mathrm{s}-$ os intervallumsebességet használtuk (VISNOvITZ 2015). A pannóniai rétegek sebességkonverzióját ugyanezzel a sebességgel végezve, igen jó korrelációt kaptunk a szeizmikus reflexiók és a fúrómagban megfigyelhetô változások között. Az illesztés alapján látható, hogy a mintavételhez szükséges fenékzárást már csak a buckákat tartalmazó agyagos képződményben lehetett megvalósítani, emiatt a 6 . ábrán p-4-ként jelölt ciklushatár és a felette elhelyezkedô üledékek mintázására, és az üledékek korának meghatározására sajnos nem volt lehetőségünk.

Az illesztés szerint a fúrás első 1,5 méteres szakasza (M1) teljes egészében a mintázni kívánt bucka anyagát tartalmazza. Ez alapvetően puhatestúhéjakat és azok töredékét tartalmazó, szerkezetmentes agyag, amely lefelé aleuritos agyagba megy át. A bucka talpát az alig észlelhető litológiai változás (héjtöredékek és apró deformációs szerkezetek az agyagban) mellett a gamma-intenzitás és szuszceptibilitás görbék kisebb kitérése, trendváltozása mutatja.

A 2. mag (M2) már a bucka talpa alatti, szeizmikusan jól rétegzett egységet harántolta, mely a harmadik mag (M3) elejéig tart és sötétszürke, aleuritos agyagból áll. A szeizmikus szelvényen ennek talpát jelöli a ( $p-3)$ felület, melyet SACCHI et al (1999) a Pan-2 szekvenciahatárral azonosított, részben az alatta fellapolódással végződő ferde reflexiók miatt. Ez a felszín a fúrásban is megvan és egy olyan transzgresszív felületként értelmezhetô, mely az alatta települő deltasorozat felső részében található sárgásbarna, finomszemcsés homokot és az elöntést követően lerakódott szürke nyíltvízi agyagot választja el egymástól. A laza, finomszemcsés homokot a fúró nem volt képes kiemelni, emiatt a következô magszakaszok (M3, M4, M5) erôsen maghiányosak. Magot legközelebb abból a mélységből sikerült venni, 


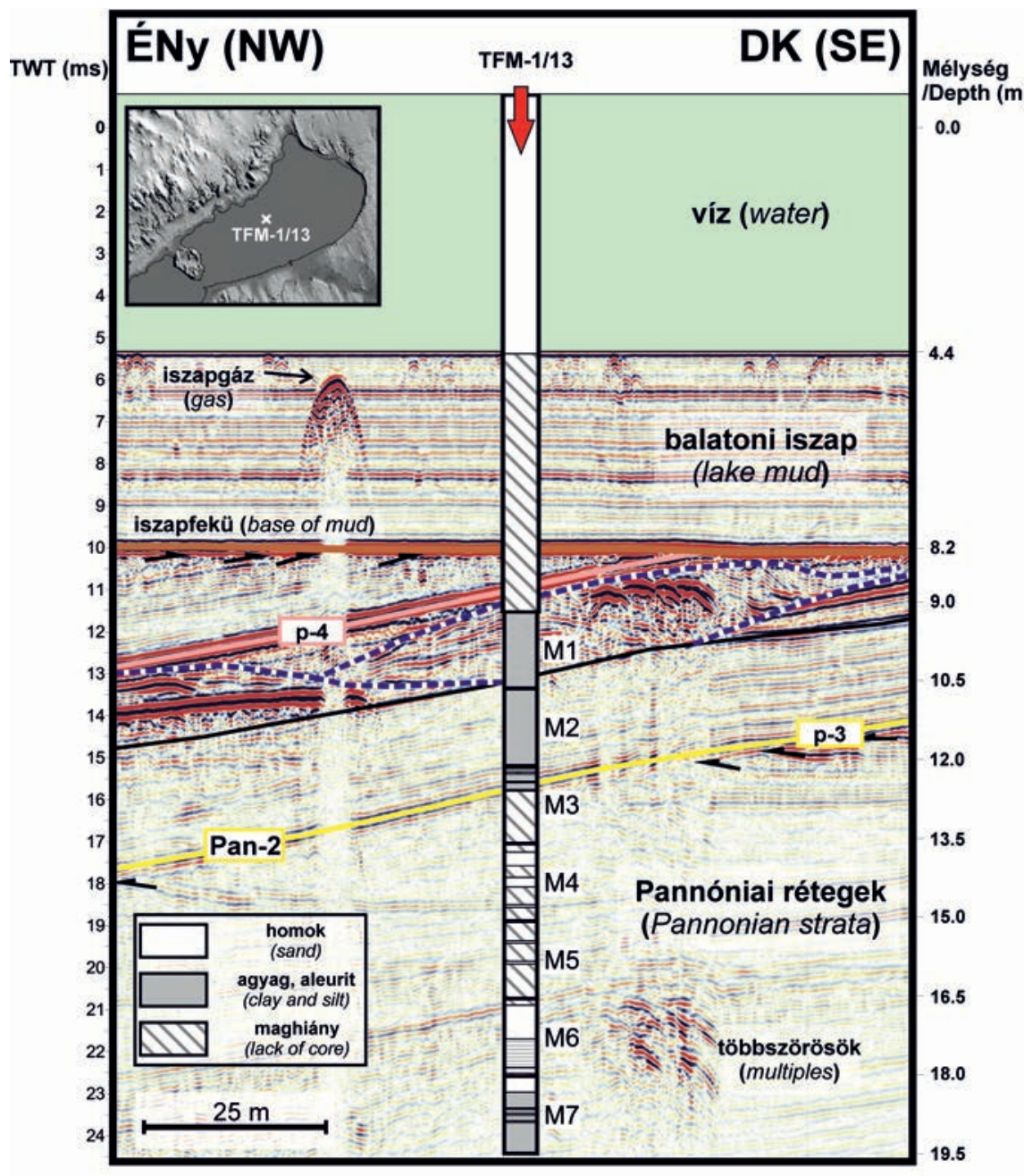

6. ábra. A különböző magszakaszok (M1-M7) illesztése az ultranagy felbontású szeizmikus adatokhoz A nyilak a p-3 (Pan-2) határ alatt fellapolódó reflexió-elvégződéseket jelölik

Figure 6. Cores (M1-M7) and their correlation with ultra-high resolution seismic data. Black arrows mark the reflection terminations (toplaps) on p-3(Pan-2) horizon

ahol már valamivel kötöttebb és agyagosabb, finom-aprószemcsés homok volt jelen. A fúrás alsó $2 \times 1,5$ méteres szakaszában (M6, M7 mag) finom-aprószemcsés, aleuritos homok, majd rétegzetlen agyag volt az uralkodó kôzettípus.

A fúrás alapján egyértelmú, hogy a harántolt buckás alakzat nem édesvízi vagy kovás mészkőből áll, melyet a Tihanyifélszigeten „gejzirit” kúpokként láthatunk. A fúrt rétegsor ugyanazokat az agyagos-homokos képződményeket tartalmazza, mint amit a Balaton környéki feltárásokból, mint Tihanyi Tagozat ismerünk. A buckák képződésére a Tihanyi Tagozat képződési környezetének ismeretében, azaz deltalebenyek frontján — deltasíkság feltöltődésével kapcsolatosan (SzTANó \& MAGYAR 2007, SzTANó et al. 2013, VISNOVITZ 2015) kell magyarázatot találni. A 7. ábrán a mintázott bucka két különbözó metszete és annak értelmezése látható, a 2013-as szeizmikus szelvénypáron. A szelvényeket a buckák alatti $p-3(P a n-2)$ határra egyenesítettük ki, mely egykor közel vízszintes lehetett. A buckák teteje a párhuzamos $p-4$ paraszekvenciahatár alatt húzódó, helyenként a $p-4$ horizont által lefejezett reflexió, talpa pedig a $p-3$ és $p-4$ határok közötti lejtôs reflexió, mely a fúrásban aleuritos agyagnak bizonyult. A buckák a kis dőlésszögú felszín felett kis méretû rátolódások sorozataként feltorlódott rétegkötegeket alkotnak, melyet a csuszamlás alsó, kompressziós szakaszaként értelmezhetünk. Ugyanez a jelleg keresztmetszetben héjas struktúraként jelentkezik, melyet a fiatalabb üledékek mindkét oldalról rálapolódással beburkolnak.

Hasonló üledékes redókre és rátolódásokra sok példát találhatunk. Ilyet figyeltek meg például a délkelet-spanyolországi Baza-medence pleisztocén deltaüledékeiben is (GIBERT et al. 2005), ahol a buckák talpát szintén agyagos képződmények alkotják, a buckák anyaga azonban elsősorban homokos üledékből áll. A szerzők a szerkezetet olyan víz alatti, deltaelőtéri csuszamlásként értelmezték, melyek egy igen lapos $\left(<1^{\circ}\right)$ lejtőn, feltehetóleg egy földrengés hatására alakultak ki. ALSOP \& MARCO (2013) a fentieknél sokkal bonyolultabb csuszamlásiredô-geometriákat ismertettek, a csuszamlásban résztvevő anyag és a csuszamlás fejlettségétől függő́en. Lejtőkön vagy lejtők tövében kialakuló kilométer nagyságrendú csuszamlások geometriáját részletgazdagon képezték le szeizmikus szelvényekkel, valamint megkülönböztették a fronton korlátozott és szabadon szétterülő típusokat (FrEY-MARTINEZ et al. 2006). Ennek figyelembe vételével itt inkább a szabad végú geometria a valószínúbb.

A buckák alatt sehol sem láttunk a feküt átszakító közel függőleges mintázatot. Ugyan köztudottan a módszer nem alkalmas vertikális struktúrák leképezésére, úgy véljük, ha léteznének, legalább valamilyen zavarként leképződtek volna. Ezek hiányában az iszapdiapír, vagy egyéb telérekhez kapcsolódó deformációs szerkezet értelmezést elvetettük. A balatoni példa esetében a buckák belsô szerkezete egyelőre nehezen magyarázható másként mint csuszamlás eredetú redőkkel, rátolódásokkal, emiatt úgy véljük, hogy a buckák többsége csuszamlásos eredetú. A rátolódások alapján a mozgás látszólag ÉNy-i irányú, ami a buckák ugyanilyen irányú megnyúlásával párhuzamos. Ez az irány azonban látszólag ellentétes a kapcsolódó csúszósík dôlésével, amit magyarázhatunk esetleg a csuszamlás elülső (vagy oldalsó) rámpájaként. Ez azonban nem magyarázza meg, hogy miért a feltételezett fó beszállítási irány felé történhetett a mozgás.

A kisebb és nagyobb izraeli példák (FreY-MARTINEZ et al. 2005, 2006; Alsop \& MARCO 2013) mindegyikén előfordul a lejtô csapásával párhuzamos vergenciájú redôződés 


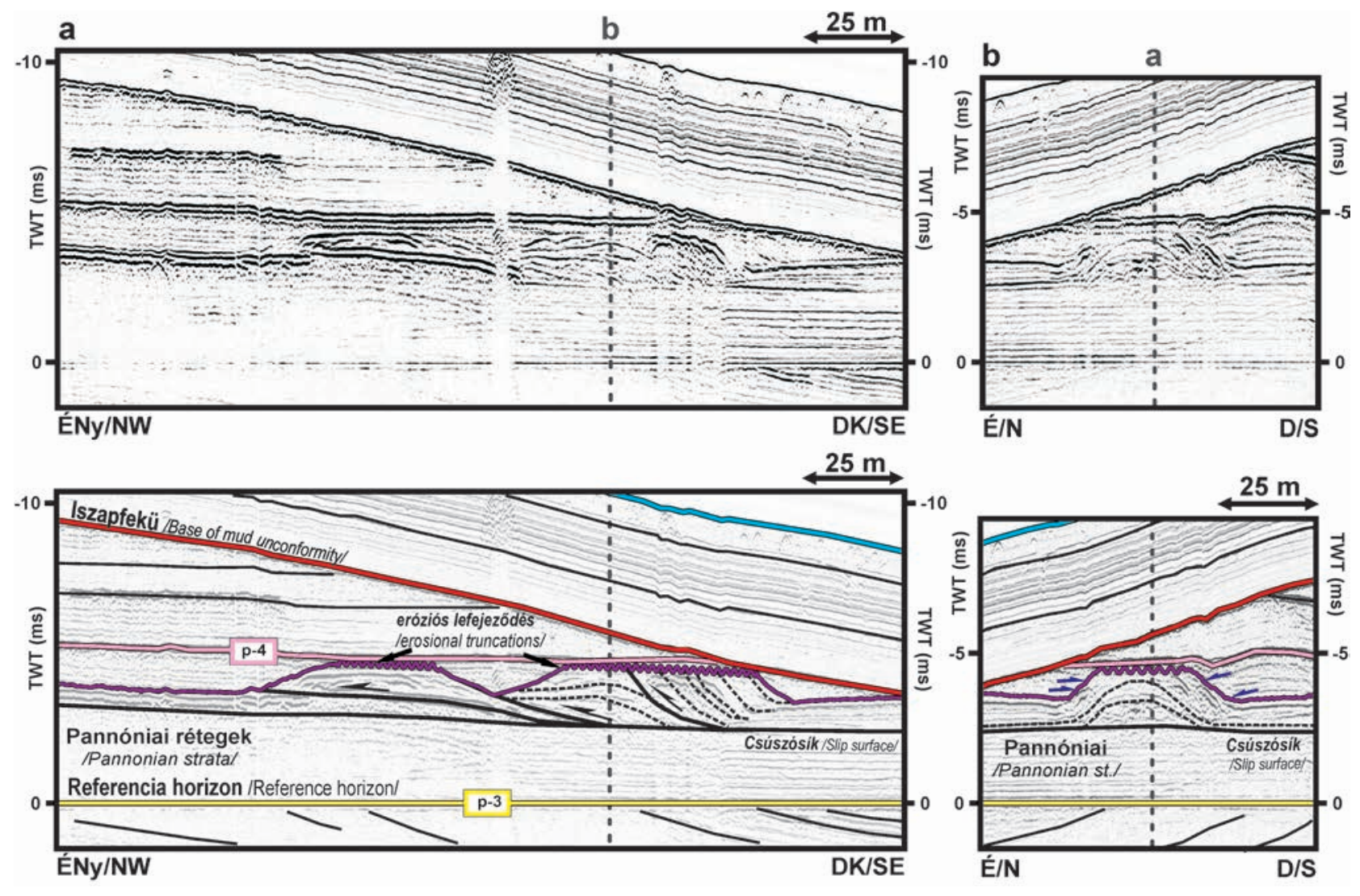

7. ábra. A vizsgált buckák hossz- (a) és keresztmetszeti képe (b) a p-3 (Pan-2) határra kiegyenesített ultranagy felbontású szeizmikus szelvényeken, melyek helyszinrajzát a 2. ábra mutatja

Figure 7. Longitudinal (a) and cross-section (b) view of the investigated mounded features in ultra-high resolution seismic profiles flattened to the p-3 horizon (location see in Figure 2)

is. Továbbá komplex, hajladozó lejtőgeometria miatt ilyen redők megjelenhetnek nem a csúszást kiváltó, hanem szomszédos lejtők lábánál is. A mozgás iránya tehát nem szükségszerúen kell kövesse a rátolódásokat, így az ÉNy-i irányt sem.

A pannóniai összlet,„buckái” a Siófoki-medence középsô részén több mint $100 \mathrm{~km}^{2}$-es területen, valószínúleg több különböző torkolathoz tartozó deltalebenyben, és nem egy szabálytalan lefutású deltafronttal párhuzamosan nyomozhatók. Ez a képződmények korára, egyidejűségére nézve kérdéseket vet fel. Szeizmikus sztratigráfiai szempontból, mivel a buckák mindegyike a $p-3$ (Pan-2) és $p-4$ között található egykorúak. Hogy a $p-3-p-4$ intervallum százezer évet reprezentál-e vagy kevesebbet, annak megbecslésére nincsenek adataink. Ugyanakkor bármely időpillanatra akár több aktív torkolatot feltételezve is a lebenyek frontja egy nagyjából kilométer széles hajladozó sáv lehet, amely mentén csuszamlások kialakulhattak. A deltafront gyors tovább épülésével kis idő múltával akár több csuszamlás generáció is létrejöhetett, ezek szétválasztására és a buckaképződés pontos időbeli lefutásának rekonstruálására azonban sajnos nincs lehetőségünk. A csuszamlásokat kiválthatta akár évszázados nagy árvizek gyors üledéklerakódása, de az sem kizárt, hogy kialakulásuk részben vagy egészében egy vagy több paleoföldrengéshez köthető.

\section{A buckás alakzatok kora}

A Be-izotópos koradatok, a magneto- és biosztratigráfiai adatok és a szeizmikus rétegtan alapján igyekeztünk megadni a buckák keletkezési korát is ( 8 a ábra). A legújabb szelvényeken alapuló szeizmikus rétegtani vizsgálatok azt mutatták, hogy a kapcsolódó rétegtani szint nem egykorú a Tihanyi Tagozat fehérparti feltárásban feltárt tetőszintjével, melyre a gejzirit települ, hanem annál idősebb. A kérdéses felszín a partközeli szeizmikus szelvények alapján 4-5, negyedrendú üledékciklussal előbb keletkezhetett. A buckák tehát idősebbek, mint a tihanyi vulkanizmus (kb. 8 M év, WiJBRANs et al. 2007), sốt idősebbek, mint a fehérparti feltárás (kb. 8,0-8,1 vagy 8,2-8,3 M év között, SzTANó et al. 2013a). Feltételezve, hogy a negyedrendú ciklusok időtartama közel 150 ezer év a buckákhoz tartozó üledékek kora kb. 8,4-8,75 millió évre adódna, ami hibahatáron belül megegyezik a meghatározott Be-korral, és nem mond ellent a Lymnocardium decorum zónának sem. Utóbbi feltételezés azt jelentené, hogy a balatoni szeizmikán azonosítható ciklushatárok azonos hierarchiájú egységekhez tartozhatnak, mint amelyeket a Makói-árokban (SzTANó et al. 2013b), vagy a somogyi területeken (TöRô et al. 2012) korábban kimutattak.

Amennyiben a berilliumos kormeghatározás közelítőleg helyes, a Balaton alatt korábban kijelölt Pan-2 felszín, mely 
nem azonos a tihanyi gejziritek szintjével, valóban olyan — esetleg harmadrendú — szekvenciahatárt jelölhet, melyhez kb. 0,5 millió éves hiátus tartozhat, ugyanabban az üledékképződési környezetben és formációban. Ebben az esetben a $p-3$ felszín alól származó minták reverz polaritását is figyelembe véve a kérdéses üledékciklus a C4Ar kronhoz $(9,1-$ 9,8 M év) tartozna. A Pannon-tó és a kisalföldibakonyi régió fejődéstörténetéról alkotott képbe (Magyar et al. 2007, CzICZER et al. 2008, SzTANó et al. 2013a), ez az adat egyelőre nem illeszthető be.

\section{Konklúziók}

A 2013 októberében mélyített TFM-1/13 jelú balatoni mederfúrás új adatokat szolgáltatott a harántolt pannóniai rétegek anyagát és korát illetően, valamint módosította a vízi szeizmikus szelvények és a fehérparti feltárás korrelációját. A 19,50 méteres talpmélységú, célzott mintavételre mélyített fúrás kimutatta, hogy a tó alatt korábban édesvízi mészkőkúpokként értelmezett nagy amplitúdójú buckás alakzatok valójában agyagos üledékekből állnak, így a tihanyi gejziritekkel nem korrelálhatók.

A fúrás által harántolt agyagos-homokos rétegsor jellegében a fehérparti feltárásból ismert üledékekhez hasonló, így kőzetrétegtanilag a Tihanyi Tagozat részeként értelmezhető. A mintázott üledékek kora mind magnetosztratigráfiai, mind Beizotópos vizsgálatok, mind pedig az új szeizmikus korrelációk alapján idősebbnek bizonyult a tihanyi Fehérpart rétegsoránál.

A buckás alakzatokat csuszamlások feltorlódó talpi redőiként, rátolódásokként értelmezzük, melyek az egykori deltaelőtéri agyagok deformációjával képződhettek. A buckák keletkezésének okát és kapcsolatát az egykorú deltalejtővel azonban még nem tudjuk egyértelmúen magyarázni. A csuszamlási szerkezetekből levezethető csúszási irányok és a feltételezett paleolejtô dőlések ugyanis nincsenek összhangban egymással. A képződmények jól meghatározott rétegtani helyzete és nagy területi előfordulása ugyanakkor arra utalnak, hogy ezeknek a csuszamlási szerkezeteknek a keletkezése idején, valamikor 8,4-8,7 M év között, gyakoriak lehettek az olyan nagyobb áradások, melyek lejtôinstabilitáshoz vezettek. Lehetséges, hogy a csuszamlások részben vagy egészében egy vagy több paleoföldrengéshez köthetők. Utóbbi rengéseket a vulkanizmushoz az időbeli eltérés miatt úgy tûnik, nem köthetjük.

A mag alsó szakaszának Be-korokra alapozott 9,1-9,8 millió éves kora nem illeszthető a Kisalföld-Dunántúli-középhegység fejlődéstörténetérôl alkotott jelenlegi képbe. Amennyiben ez az adat helytálló, úgy a régió késő-miocén fejlődéstörténetét jelentősen át kellene írni. A fúrás felsô és

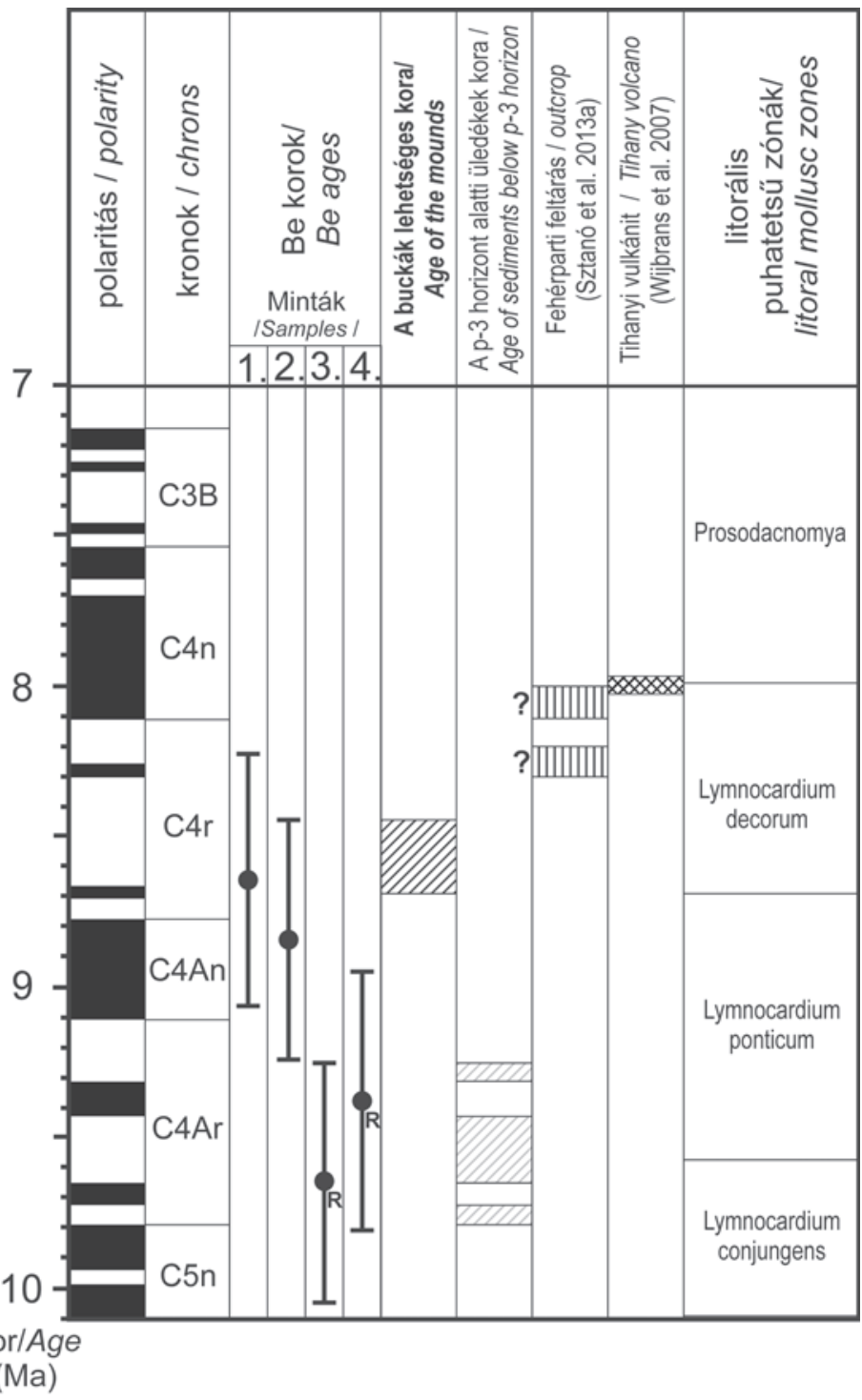

8. ábra. A TFM-1/13 fúrásból származó mintákon mért korok összevetése a globális polaritás időskálával (GPTS, HILGEN et al. 2012 szerint), a biozónákkal (MAGYAR 2010) és a fehérparti feltárásban meghatározott korokkal. A fekete, ferdén sraffozott tartomány a fúrás felső részéből származó minták lehetséges korát jelöli a Be-izotópos mérések és a biosztratigráfia vizsgálatok alapján, míg a szürkén sraffozott tartományok a fúrás alsó szakaszából vett minták lehetséges korát mutatják a Be-izotópos mérések és a fúrómag reverz polaritását figyelembe véve. R: fordított mágneses polaritás

Figure 8. Comparison of the ages measured on TFM-1/13 core samples with global polarity time scale (GPTS, HILGEN et al. 2012), biostratigraphic zones (MAGYAR 2010) and possible ages of the Fehérpart outcrop, Tihany peninsula. Black striped interval show the possible ages for samples from the upper part of the core based on Be isotope data and biostratigraphy while zones striped by grey lines give the possible ages for the samples from the lower part of the core regarding Be ages and magnetic polarity of the samples. R: Reverse magnetic polarity

alsó része között elhelyezkedő Pan-2 szekvenciahatár (cf. SACCHI et al. 1998, HoRvÁTH et al. 2010), ez esetben 0,5 millió éves hiányt képviselhet.

\section{Köszönetnyilvánítás}

A balatoni szeizmikus felmérésekben nélkülözhetetlen együttmúködő partnereink voltak az ELTE geofizikus hallgatói, a Geomega Kft. és a Brémai Egyetem Marine Tech- 
nology - Environmental Research kutatócsoportja. Külön köszönet illeti TóTH Tamást a kutatásokhoz szükséges múszerek, és szakértőgárda rendelkezésre bocsátásáért. A balatoni mederfúrásnál a Geovil Kft. és az Óriás Line Kft. voltak segítségünkre. A fúrási munkák sikeres lebonyolításáért HoRvÁTH Tibornak és †DoBOs Istvánnak mondunk köszönetet. A fúrás kijelölését célzó felméréseket a Pázmány-Eötvös Információs Alapítvány támogatta, a felmérést a Yachtsail Kft. és SzABó Lajos hajóskapitány közremúködésével végeztük. A minták magnetosztratigráfiai vizsgálatát az Utrechti Egyetem Paleomágneses Laboratóriumában, a Be-izotópos kormeghatározásokat az
ASTER AMS (CERGE, Aix en Provance) laboratóriumában végeztük. A fúráshoz és a kapcsolódó szeizmikus kutatásokhoz az OTKA NK83400 és 109255 K projektek biztosították az anyagi támogatást, a Be-izotópos kormeghatározásokat a Szlovák Kutatás-fejlesztési Ügynökség (Slovak Research and Development Agency) APVV-140118 és APVV-0099-11 projektjei és a francia INSU/CNRS kiválósági projektje finanszírozta. A szeizmikus adatok értelmezéséhez az IHS Kingdom értelmező szoftvert az IHS cég University Grant támogatási programja biztosította. A cikk egyben az MTA-MTM-ELTE Paleontológiai Kutatócsoportjának 251. közleménye.

\section{Irodalom - References}

Alsop, G. I. \& MARCO, S. 2013: Seismogenic slump folds formed by gravity-driven tectonics down a negligible subaqueous slope. Tectonophysics 605, 48-69. http://doi.org/10.1016/j.tecto.2013.04.004

Bada G., Szafián P., Vincze O., Tóth T., Fodor L., Spiess, V. \& Horváth F. 2010: Neotektonikai viszonyok a Balaton keleti medencéjében és tágabb környezetében nagyfelbontású szeizmikus mérések alapján. — Földtani Közlöny 140/4, 367-390.

Balázs A., Visnovitz F., Spiess, V., FeKete N., Tóth Zs., Hámori Z., Kudó I. \& Horváth F. 2013: Új szeizmikus mérések a Balatonon: beszámoló a 2011-2012. évi szelvényezésekről. —Magyar Geofizika 54/2, 67-76.

BosnAKoff M. 2013: A Pannon-tó halfaunájának taxonómiai, őskörnyezeti és evolúciós vizsgálata. — PhD értekezés, ELTE Őslénytani Tanszék, Budapest, $132 \mathrm{p}$.

Bourles, D., Raisbeck, G. M. \& Yiou, F. 1989: ${ }^{10} \mathrm{Be}$ and ${ }^{9} \mathrm{Be}$ in marine sediments and their potential for dating. - Geochimica et Cosmochimica Acta 53, 443-452. http://doi.org/10.1016/0016-7037(89)90395-5

CSERnY T. 2002: A balatoni negyedidőszaki üledékek kutatási eredményei. — Földtani Közlöny 132/különszám, 193-213.

CSERNY T. \& CORRADA, R. 1989: A Balaton medencéje és holocén üledékei részletes geofizikai-földtani vizsgálatának újabb eredményei. - A MÁFI Évi Jelentése 1987. évról, 341-347.

CSERny, T. \& Corrada, R. 1990: A Balaton aljzatának szedimentológiai térképe. — A MÁFI Évi Jelentése 1988. évról, 169-176.

CsillaG G., SzTANó O., Magyar I. \& HÁmori Z. 2010: A Kállai Kavics települési helyzete a Tapolcai-medencében geoelektromos szelvények és fúrási adatok tükrében. — Földtani Közlöny 140/2, 183-196.

Cziczer, I., Magyar, I.., Pipík, R., Böhme, M., Ćorić, S., Bakrač, K., Sütő-Szentai, M., Lantos, M., Babinszki, E. \& Müller, P. 2008: Life in the sublittoral zone of long-lived Lake Pannon: paleontological analysis of the Upper Miocene Szák Formation, Hungary. - International Journal of Earth Sciences 98, 1741-1766. http://doi.org/10.1007/s00531-008-0322-3

DANKERS, P. H. M. \& ZiJDERVELD, J. D. A. 1981: Alternating field demagnetization of rocks, and the problem of gyromagnetic remanence. —Earth and Planetary Science Letters 53, 89-92. http://doi.org/10.1016/0012-821x(81)90029-7

Frey-Martinez, J., Cartwright, J. \& Hall. B. 2005: 3D seismic interpretation of slump complexes: examples from the continental margin of Israel. — Basin Research 17, 83-108. http://doi.org/10.1111/j.1365-2117.2005.00255.x

Frey-Martinez, J., CARTwright, J. \& JAMES, D. 2006: Frontally confined versus frontally emergent submarine landslides: A 3D seismic characterisation. - Marine and Petroleum Geology 23, 585-604. http://doi.org/10.1016/j.marpetgeo.2006.04.002

Gibert, L., Sanz de Galdeano, C., Alfaro, P., ScotT, G. \& LóPez Garrido, A. C. 2005: Seismic-induced slump in Early Pleistocene deltaic deposits of the Baza Basin (SE Spain). — Sedimentary Geology 179, 279-294. http://doi.org/10.1016/j.sedgeo.2005.06.003

Hilgen, F. J., Lourens, L. J. \& van Dam, J. A. 2012: The Neogene Period. — In: Gradstein, F., OgG, J., Schmitz, M. \& OgG, G. (eds): The Geological Time Scale 2012. — Elsevier, Amsterdam, 923-978. http://doi.org/10.1016/b978-0-444-59425-9.15001-2

Horváth F., SACCHI M. \& DombRÁDi E. 2010: A Pannon-medence üledékeinek szeizmikus sztratigráfiai és tektonikai vizsgálata a DélDunántúl és a Balaton területén. — Földtani Közlöny 140/4, 391-418.

KIRSCHVINK, J. 1980: The least squares lines and plane analysis of paleomagnetic data. _ Geophysical Journal of the Royal Astronomical Society 62, 699-718.

KollmanN, K. 1960: Cytherideinae und Schulerideinae n. subfam. (Ostracoda) aus dem Neogen des östlichen Österreich. Mitteilungen der Geologischen Gesellschaft in Wien 51, 89-195.

Lebatard, A., Bourlès, D. L., Braucher, R., Arnold, M., Duringer, P., Jolivet, M., Moussa, A., Deschamps, P., Roquin, C., Carcaillet, J., Schuster, M., Lihoreau, F., Likius, A., Mackaye, H. T., Vignaud, P. \& Brunet, M. 2010: Application of the authigenic ${ }^{10} \mathrm{Be} /{ }^{9} \mathrm{Be}$ dating method to continental sediments: Reconstruction of the Mio-Pleistocene sedimentary sequence in the early hominid fossiliferous areas of the northern Chad Basin. — Earth and Planetary Science Letters 297, 57-70. http://doi.org/ 10.1016/j.eps1.2010.06.003

Lóczy L. 1913: A Balaton környékének geológiai képződményei és ezeknek vidékek szerinti telepedése. — In: LócZY L. (szerk.): A Balaton tudományos tanulmányozásának eredményei. I. kötet, 1. rész, 1. szakasz. — Budapest, Kilián F. Bizománya, 617 p.

MAGYAR I. 2010: A Pannon-medence ösföldrajza és környezeti viszonyai a késốmiocénben. — Geolitera, Szeged, 140 p. 
MagYAR, I., LANTOS, M., UjSZÁszI, K. \& KoRdos, L. 2007: Magnetostratigraphic, seismic and biostratigraphic correlations of the Upper Miocene sediments in the northwestern Pannonian Basin System. — Geologica Carpathica 58, $277-290$.

Magyar, I., Radivojević, D., Sztanó, O., Synak, R, Ujszászi, K. \& PócsiK, M. 2013: Progradation of the paleo-Danube shelf margin across the Pannonian Basin during the Late Miocene and Early Pliocene. _ Global and Planetary Change 103, 168-173. http://doi.org/10.1016/j.gloplacha.2012.06.007

Márton P., Babinszki E., Dövényi P., Drahos D., Galsa A., Horváth F., Lipovics T., Mártonné Szalay E., Puszta S., Salát P., SurÁNYi G., SzÉKElY B., Tóth T. \& WindHOFFER G. 2007: Integrált kutató módszer kifejlesztése negyedidőszaki környezeti állapotok geofizikai vizsgálatára (Development of an integrated research method for the geophysical investigation of environmental conditions in the Quaternary). —Zárójelentés a T 44765 sz. OTKA pályázathoz.(2003-2005), 23 p.

NovÁK D., Koncz D., HoRvÁth A., SzAFIÁN P. \& SzTANó O. 2010: Egy pleisztocén folyó kanyarulata Fonyódnál: medernyomok a balatoni iszap alatt ultranagy felbontású szeizmikus szelvényeken. — Földtani Közlöny 140/4, 419-428.

Rundić, L., Ganić, M., Knezević, S. \& Soliman, A. 2011: Upper Miocene Pannonian sediments from Belgrade (Serbia): new evidence and paleoenvironmental considerations. — Geologica Carpathica 62/3, 267-278. http://doi.org/10.2478/v10096-011-0021-z

Sacchi, M., Cserny, T., Dövényi, P., Horváth, F., Magyari, O., McGee, T. M., Mirable, L. \& Tonielli, R. 1998: Seismic stratigraphy of the Late Miocene sequence beneath Lake Balaton, Pannonian basin, Hungary. _ Acta Geologica Hungarica 41/1, 63-88.

SACCHI, M., HorvÁTH, F. \& MAGYARI, O. 1999: Role of unconformity-bounded units in the stratigraphy of the continental record: a case study from the Late Miocene of the western Pannonian basin, Hungary. — In: Durand, B., Jolivet, L., Horváth, F. \& SÉranne, M. (eds): The Mediterranean Basins: Tertiary Extension within the Alpine Orogen. _ Geological Society, London, Special Publications 156, 357-390. http://doi.org/10.1144/gsl.sp.1999.156.01.17

Šujan, M., Braucher, R., Kováč, M., Rybár, S., Guillou, V., Bourlès, D., Baranyi, V. \& HudáčKová, N. 2015: Upper Miocene to Quaternary evolution of the Danube Basin inferred from the authigenic ${ }^{10} \mathrm{Be} /{ }^{9} \mathrm{Be}$ dating method results. — In: BARTHA I. R., KRIVÁN Á., Magyar I. \& Sebe K. (eds): 6th Workshop on the Neogene of Central and South-Eastern Europe Conference, Orfü, Magyarország, Absztrakt kötet (kiadta a Magyarhoni Földtani Társulat), 87-88.

Šujan, M., Braucher, R., Kováč, M., Bourlès, D. L., Rybár, S., Guillou, V. \& HudáčKovÁ, N. 2016: Application of the authigenic ${ }^{10} \mathrm{Be} /{ }^{9} \mathrm{Be}$ dating method to Late Miocene - Pliocene sequences in the northern Danube Basin (Pannonian Basin System): Confirmation of heterochronous evolution of sedimentary environments. — Global and Planetary Change 137, 35-53. http://doi.org/ 10.1016/j.gloplacha.2015.12.013

SzTANó, O. \& MAGYAR, I. 2007: Deltaic parasequences on gamma logs, ultra-high resolution seismic images and outcrops of Lake Pannon deposits. - Joannea Geologie und Palaontologie 9, 105-108.

Sztanó O., Magyar I., Szónoky M., Lantos M., Müller P., Lenkey L., Katona L. \& Csillag G. 2013a: A Tihanyi Formáció a Balaton környékén: típusszelvény, képződési körülmények, rétegtani jellemzés. — Földtani Közlöny 143/1, 445-468.

Sztanó, O., Szafián, P., Magyar, I., Horányi, A., BadA, G., Hughes, D., Hoyer, D. \& Wallis, R. 2013b: Aggradation and progradation controlled clinothems and deep-water sand delivery model in the Neogene Lake Pannon, Makó Trough, Pannonian Basin, SE Hungary. — Global and Planetary Change 103, 149-167. http://doi.org/10.1016/j.gloplacha.2012.05.026

Szuromi-Korecz A. 1989: DK-Dunántúl pannóniai s. 1. Ostracoda fauna vizsgálatának eredményei. — PhD értekezés, ELTE Általános és Alkalmazott Földtani Tanszék, 245 p.

Tóth Zs., Tóth T., Szafián P., Horváth A., Hámori Z., Dombrádi E., Fekete N., Spiess V. \& Horváth F. 2010: Szeizmikus kutatások a Balatonon. - Földtani Közlöny 140/4, 355-366.

TÖRŐ B., SzTANÓ O. \& FoDOR, L. 2012: Aljzatmorfológia és aktív deformáció által befolyásolt pannóniai lejtőépülés Észak-Somogyban. - Földtani Közlöny 142/4, 445-468.

ViSNOVITZ F. 2015: Balatoni vízi szeizmikus szelvények környezetgeofizikai vizsgálata. — PhD értekezés, ELTE Geofizikai és Ürtudományi Tanszék, Budapest, 165 p. + mellékletek. http://doi.org/10.15476/ELTE.2015.138

Visnovitz F., Tóth T, Hámori Z., Kudó I., Balázs A., Sacchi, M., Surányi G. \& Horváth F. 2013: Balatoni egycsatornás, nagy felbontású szeizmikus szelvények újrafeldolgozása. — Magyar Geofizika 54/2, 77-88.

Visnovitz, F., Horváth, F. \& SurÁnYI, G. 2014: Geometry-Lithology-Origin: Solving the mystery of the Late Miocene mounded features below Lake Balaton. — Geophysical Research Abstracts 16, EGU2014-781-2.

Visnovitz, F., Horváth, F., Fekete N. \& SpIESs, V. 2015a: Strike-slip tectonics in the Pannonian basin based on seismic surveys at Lake Balaton. - International Journal of Earth Sciences 104, 2273-2285. http://doi.org/10.1007/s00531-015-1179-X

Visnovitz, F., Bodnár, T., Tóth, Zs., Spiess, V., Kudó, I., Timár, G. \& Horváth, F. 2015b: Seismic expressions of shallow gas in the lacustrine deposits of Lake Balaton, Hungary. — Near Surface Geophysics 13, 433-446. http://doi.org/10.3997/1873-0604.2015026

Wijbrans, J., NÉMeth, K., Martin, U. \& BALOGH, K. 2007: ${ }^{40} \mathrm{Ar} /{ }^{39}$ Ar Geochronology of Neogene phreatomagmatic volcanism in the Western Pannonian Basin, Hungary. — Journal of Volcanology and Geothermal Research 164, 193-204. http://doi.org/10.1016/ j.jvolgeores.2007.05.009

ZiJderveld, J. 1967: A. C. demagnetization of rocks: Analysis of results. — In: Collinson, D. W., CREER, K. M. \& RunCORN, S. K. (eds): Methods in Paleomagnetism. — Elsevier, Amsterdam, 254-286.

ZlinszKy A., Molnár G. \& SzÉKely B. 2010: A Balaton vízmélységének és tavi üledékvastagságának térképezése vízi szeizmikus szelvények alapján. — Földtani Közlöny 140/4, 429-438.

Kézirat beérkezett: 2017. 01. 26. 
